\title{
ANALISIS PENGEMBANGAN BUDIDAYA RUMPUT LAUT Gracillaria sp DI KECAMATAN SINJAI TIMUR KABUPATEN SINJAI
}

\author{
Analysis of Seaweed Gracillaria sp Culture Development in East Sinjai District, Sinjai Regency \\ Irmawati Malkab $^{1}$, Hadijah ${ }^{2}$ dan Sri Mulyani ${ }^{2}$ \\ ${ }^{1}$ Dinas Perikanan dan Kelautan Kabupaten Sinjai, Sulawesi Selatam \\ ${ }^{2}$ Program Studi Budidaya Perairan Fakultas Pertanian Universitas Bosowa \\ Email : iramwatimalkab@yahoo.com
}

Diterima: 03 Februari 2021

Dipublikasikan: 15 Juni 2021

\begin{abstract}
ABSTRAK
Kondisi lingkungan perairan tambak terutama dari aspek kualitas fisika dan kimia perairan sangat menentukan keberhasilan budidaya rumput laut gracilaria sp. Tujuan penelitian ini adalah menganalisis parameter fisika dan kimia air tambak yang mendukung pengembangan budidaya rumput laut dan penentuan lokasi yang sesuai untuk pengembangan budidaya rumput laut ditinjau dari aspek fisika dan kimia air di empat desa/Kelurahan Kecamatan Sinjai Timur Kabupaten Sinjai. Dilaksanakan pada bulan Januari sampai Februari 2016. Teknik analisis dilakukan dengan menentukan beberapa parameter fisika kimia air sebagai faktor pembatas yang terdiri dari: kecerahan, suhu, kedalaman, salinitas, $\mathrm{pH}$ $\mathrm{DO}, \mathrm{CO}_{2}$, fosfat, dan nitrat. Parameter pembatas dalam empat kelas kategori, yaitu kelas sangat sesuai, sesuai, kurang sesuai , dan tidak sesuai. Hasil Penelitian menunjukkan tambak di Kelurahan Samataring, Desa Tongke-tongke, Desa Panaikang, dan Desa Pasimarannu sesuai untuk pengembangan budidaya rumput laut gracillaria sp.
\end{abstract}

Kata Kunci: Fisika Kimia, Kesesuaian Lahan, Rumput Laut, Sinjai

\begin{abstract}
Condition pond water environment, especially from the aspect of water quality chemical physics determine the success of seaweed farming gracilaria sp. The purpose of this study was to analyze the physical and chemical parameters of water ponds, which supports the development of seaweed farming and determining a suitable site for the development of seaweed cultivation from the aspect of chemical physics of water in four villages / East Village Sinjai Sinjai district. Conducted in January and February 2016. Technical analysis is done by determining several physical parameters of water chemistry as a limiting factor consisting of: brightness, temperature, depth, salinity, pH, DO, CO2, phosphate, and nitrate. Parameters delimiter in four grade categories, namely class is suitable, appropriate, less appropriate and not appropriate. Research shows ponds in the village of Samataring, Tongke-tongke, Panaikang and pasimarannu appropriate for the cultivation of seaweed gracillaria sp.
\end{abstract}

Keywords: Aquaculture, Chemical Physical, Conformity, Seaweed, Sinjai

\section{PENDAHULUAN}

Rumput laut merupakan salah satu produk unggulan dalam kebijakan pemerintah yang akan menjadikan Indonesia sebagai penghasil produk perikanan terbesar di dunia pada tahun 2015. Keoptimisan ini didasarkan pada peningkatan produksi rumput laut Indonesia. Tahun 2011 produksi rumput laut sebesar 3,1 juta ton, pada tahun 2012 meningkat menjadi 5,1 juta ton, selanjutnya pada tahun 2014 naik menjadi 10,23 juta ton. Target produksi rumput laut untuk tahun 2019 adalah sebesar 19,5 juta ton (Kementerian Kelautan dan Perikanan 2015).

Rumput laut penghasil agar dari jenis Gracillaria sp mengalami perkembangan budidaya yang sangat pesat, khususnya di Sulawesi Selatan. Produksi jenis rumput laut ini digunakan sebagai bahan pendukung dalam industri lain, seperti industri kosmetik, farmasi dan pengalengan ikan/daging (Sadhori, 1992; Jamaluddin et al. 2020; Agustang et al., 2020). Kuantitas penggunaan ekstrak rumput laut yang terus meningkat menjadikan produksi rumput laut semakin prospek sebagai komoditas budidaya, perdagangan, serta prospektif bagi pemberdayaan dan pengentasan kemiskinan masyarakat pesisir. Peningkatan permintaan produk rumput laut, sejalan dengan pergeseran pola makan dan tuntutan kualitas kebutuhan hidup manusia. Selain kaya protein dan serat, rumput laut Gracillaria sp juga kaya dengan kandungan mineral Ca dan Fe (Mubarak, 1990).

Kecamatan Sinjai Timur, Kabupaten Sinjai yang memiliki potensi sumber daya lahan budidaya rumput laut belum dimanfaatkan secara optimal. Potensi tersebut memiliki keunggulan komparatif yang perlu mendapatkan prioritas penanganan pengembangan budidayanya agar dapat direalisasikan menjadi keunggulan kompetitif, sehingga peluang laju percepatan peningkatan produksi hasil budidaya di masa mendatangakan semakin besar. Kondisi lingkungan perairan menjadi acuan penting bagi pemilihan lokasi pengembangan kawasan budidaya rumput laut. Keberhasilan dan keberlanjutan penerapan budidaya rumput laut sangat ditentukan oleh karakteristik mutu lingkungan perairannya dan disesuaikan daya dukung lingkungan yang secara ekonomis menguntungkan. Untuk itu diperlukan dukungan penelitian dan iptek yang mantap serta ditunjang oleh strategi 
pemanfaatan sumberdaya secara rasional dan berwawasan lingkungan.

Untuk kegiatan budidaya rumput laut gracillaria sp yang berhasil guna dan berdayaguna, akan penentuan lokasi sesuai dengan kondisi perairan perlu menjadi perhatian. Satu diantara kendala dalam pengembangan budidaya rumput laut di Kabupaten Sinjai adalah masih terbatasnya data rinci dan informasi mengenai ketepatan kelayakan potensi sumberdaya tambak ditinjau dari sifat fisika kimia air yang dapat dijadikan acuan dalam mengelola sumber daya tersebut secara optimal. Diperlukan informasi sekaitan dengan kesesuaian lahan budidaya rumput laut di tambak ditinjau dari aspek fisika kimia perairan

\section{METODE PENELITIAN}

Parameter fisika kimia yang diukur langsung di lapangan meliputi suhu, kecerahan, DO, Salinitas dan $\mathrm{pH}$ dengan menggunakan alat ukur water quality cheker, Pengukuran kedalaman dilakukan dengan tali meteran yang telah dilengkapi skala dengan satuan $\mathrm{mm}$. pengukuran parameter $\mathrm{CO}_{2}$ dengan menggunakan titrasi. Parameter nitrat dan posfat dilakukan di Laboratorium kualitas Unhas Makassar.

Tahap awal dari analisis parameter fisika kimia lokasi untuk budidaya rumput laut meliputi penyusunan matriks kesesuaian berdasarkan beberapa parameter fisika kimia. Matriks ini disusun melalui studi pustaka sehingga dapat diketahui parameter-parameter pembatas yang diperlukan untuk kegiatan budidaya rumput laut Gracilaria sp. Dalam penelitian setiap parameter dibagi dalam empat kelas, yaitu kelas sangat sesuai, sesuai, kurang sesuai , dan tidak sesuai. Kelas sangat sesuai diberi skor 4 (empat), sesuai diberi skor 3 (tiga), kelas kurang sesuai diberi skor 2 (dua), dan kelas tidak sesuai diberi skor 1 (satu). Parameter yang dapat memberikan pengaruh lebih kuat diberi bobot lebih tinggi daripada parameter yang lebih lemah pengaruhnya (Neksidin $d k k$, 2013).

Total skor yang diperoleh dari hasil perkalian skor dengan bobot selanjutnya dipakai untuk menentukan kelas kesesuaian parameter fisika kimia tambak budidaya rumput laut Gracilaria sp. Nilai maksimum kesesuaian parameter fisika kimia sebesar 80. Nilai tersebut diperoleh dari skor maksimum dikali bobot. Sedangkan nilai minimum sebesar 20, nilai tersebut diperoleh dari skor minimum dikali bobot.

Penentuan interval kelas dan nilai kesesuaian parameter fisika kimia tambak untuk budidaya rumput laut digunakan rumus yang dikemukakan oleh Ariyati $d k k$ (2007) dan Yunus et al. 2019. sebagai berikut:

Dimana :

$$
I=\frac{N \operatorname{maks}-N \min }{\sum K}
$$

I $\quad=$ Interval kelas;

$\mathrm{K}=$ Jumlah kelas kesesuaian lahan yang diinginkan

$\mathrm{N}$ maks $\quad$ Nilai akhir maksimum

$\mathrm{N}$ min $\quad=$ Nilai akhir minimum

Menurut Hidayat $d k k$. (1995), pengertian skala penilaian pada setiap kolom adalah sebagai berikut :

- Sangat Sesuai (S1), apabila lahan tidak mempunyai pembatas yang berarti untuk mempertahankan tingkat pengelolaan
- yang harus ditetapkan;

- Sesuai (S2), apabila lahan mempunyai pembatas yang berarti untuk mempertahankan tingkat pengelolaan yang harus ditetapkan;

- Kurang Sesuai (N), apabila lahan mempunyai faktor pembatas cukup berat sehingga mencegah kemungkinan penggunaannya

\section{HASIL DAN PEMBAHASAN}

Hasil penelitian menunjukkan nilai parameter fisika kimia air tambak bervariasi pada setiap stasiun pengamatan. Nilai rata-rata variable uji dapat dilihat pada Tabel 1 berikut.

Tabel 1. Hasil Pengukuran Parameter Fisika dan Kimia Air Tambak di Kecamatan Sinjai Timur, Kabupaten Sinjai

\begin{tabular}{llllll}
\hline \multicolumn{1}{c}{ Parameter } & \multirow{2}{*}{ Satuan } & \multicolumn{4}{c}{ Satasiun } \\
& & \multicolumn{1}{c}{ I } & \multicolumn{1}{c}{ II } & \multicolumn{1}{c}{ III } & \multicolumn{1}{c}{ IV } \\
\hline Kecerahan & $\mathrm{Cm}$ & 45,2 & 44,9 & 40,3 & 38,6 \\
Suhu & ${ }^{\circ} \mathrm{C}$ & 32,2 & 32,3 & 31,6 & 31,5 \\
Kedalaman & $\mathrm{Cm}$ & 63 & 60 & 65 & 61 \\
Salinitas & $\mathrm{Ppt}$ & 29,1 & 29,1 & 25,7 & 25,4 \\
pH & & 6,23 & 5,88 & 6,73 & 6,65 \\
$\mathrm{DO}$ & $\mathrm{Mg} / 1$ & 3,83 & 3,85 & 3,48 & 3,60 \\
$\mathrm{CO}_{2}$ & $\mathrm{Mg} / 1$ & 2,32 & 3,45 & 1,62 & 1,97 \\
Fosfat & $\mathrm{Mg} / 1$ & 0,05 & 0,06 & 0,06 & 0,04 \\
Nitrat & $\mathrm{Mg} / 1$ & 0,28 & 0,28 & 0,28 & 0,22 \\
\hline
\end{tabular}

Pada Tabel 1 dapat dilihat rata-rata kecerahan yang diperoleh pada semua stasiun pengamatan berkisar antara 38,66 - 45,23, nilai rata-rata suhu pada semua stasiun pengamatan berkisar antara 31,54 - 32,32, dan nilai rata-rata kedalaman pada semua stasiun pengamatan adalah berkisar antara $60-65$. Selanjutnya salinitas yang diperoleh berkisar antara 25,46 - 29,17, dan $\mathrm{pH}$ yang diperoleh berkisar antara 5,88 - 6,73, pada parameter DO hasil pengamatan yang diperoleh berkisar antara $3,48-3,85$, nilai $\mathrm{CO}_{2}$ yang diperoleh pada semua stasiun berkisar antara 1,62 - 3,45. Sedangkan nilai fosfat yang diperoleh berkisar antara 0,04 - 0,06, dan nilai nitrat yang diperoleh pada semua stasiun berkisar antara $0,22-0,28$.

Tabel 2. Hasil Analisis Kesesuaian Parameter Fisika dan Kimia Air Tambak Pada Stasiun I

\begin{tabular}{lccccc}
\hline \multicolumn{1}{c}{ Parameter } & Satuan & Hasil pengamatan & Bobot & Skor & Nilai \\
\hline Kecerahan & $\mathrm{Cm}$ & 45,23 & 3 & 3 & 9 \\
Suhu & ${ }^{\circ} \mathrm{C}$ & 32,22 & 2 & 2 & 4 \\
Kedalaman & $\mathrm{Cm}$ & 63 & 2 & 4 & 8 \\
Salinitas & $\mathrm{Ppt}$ & 29,17 & 2 & 3 & 6 \\
$\mathrm{pH}$ & & 6,23 & 2 & 3 & 6 \\
$\mathrm{DO}$ & $\mathrm{Mg} / 1$ & 3,83 & 1 & 3 & 3 \\
$\mathrm{CO}_{2}$ & $\mathrm{Mg} / 1$ & 2,32 & 2 & 3 & 6 \\
Fosfat & $\mathrm{Mg} / 1$ & 0,05 & 3 & 1 & 3 \\
Nitrat & $\mathrm{Mg} / 1$ & 0,28 & 3 & 2 & 6 \\
\hline & & Total & & & 51 \\
\hline
\end{tabular}

Tabel 3. Hasil Analisis Kesesuaian Parameter Fisika dan Kimia Air Tambak Pada Stasiun II

\begin{tabular}{lccccc}
\hline Parameter & Satuan & $\begin{array}{c}\text { Hasil } \\
\text { Pengamatan }\end{array}$ & Bobot & Skor & Nilai \\
\hline Kecerahan & $\mathrm{Cm}$ & 44,99 & 3 & 3 & 9 \\
Suhu & ${ }^{\circ} \mathrm{C}$ & 32,32 & 2 & 2 & 4 \\
Kedalaman & $\mathrm{Cm}$ & 60 & 2 & 4 & 8 \\
\hline
\end{tabular}




\begin{tabular}{lccccc}
\hline Salinitas & $\mathrm{Ppt}$ & 29,13 & 2 & 3 & 6 \\
$\mathrm{Ph}$ & & 5,88 & 2 & 3 & 6 \\
$\mathrm{DO}$ & $\mathrm{Mg} / 1$ & 3,85 & 1 & 3 & 3 \\
$\mathrm{CO}_{2}$ & $\mathrm{Mg} / 1$ & 3,45 & 2 & 4 & 8 \\
Fosfat & $\mathrm{Mg} / 1$ & 0,06 & 3 & 2 & 6 \\
Nitrat & $\mathrm{Mg} / 1$ & 0,28 & 3 & 2 & 6 \\
\hline \multicolumn{5}{r}{ Total } \\
\hline
\end{tabular}

Tabel 4. Hasil Analisis Kesesuaian Parameter Fisika dan Kimia Air Tambak Pada Stasiun III

\begin{tabular}{lccllc}
\hline \multicolumn{1}{c}{ Parameter } & Satuan & $\begin{array}{c}\text { Hasil } \\
\text { Pengamatan }\end{array}$ & Bobot & Skor & Nilai \\
\hline Kecerahan & $\mathrm{cm}$ & 40,35 & 3 & 2 & 6 \\
Suhu & ${ }^{\circ} \mathrm{C}$ & 31,67 & 2 & 3 & 6 \\
Kedalaman & $\mathrm{cm}$ & 65 & 2 & 4 & 8 \\
Salinitas & $\mathrm{ppt}$ & 25,78 & 2 & 4 & 8 \\
$\mathrm{Ph}$ & & 6,73 & 2 & 3 & 6 \\
$\mathrm{DO}$ & $\mathrm{Mg} / 1$ & 3,48 & 1 & 3 & 3 \\
$\mathrm{CO}$ & $\mathrm{Mg} / 1$ & 1,62 & 2 & 3 & 6 \\
Fosfat & $\mathrm{Mg} / 1$ & 0,06 & 3 & 2 & 6 \\
Nitrat & $\mathrm{Mg} / 1$ & 0,28 & 3 & 2 & 6 \\
\hline & & Total & & 55 \\
\hline
\end{tabular}

Tabel 5. Hasil Analisis Kesesuaian Parameter Fisika dan Kimia Air Tambak Pada Stasiun IV

\begin{tabular}{lccccc}
\hline \multicolumn{1}{c}{ Parameter } & Satuan & Hasil Pengamatan & Bobot & Skor & Nilai \\
\hline Kecerahan & $\mathrm{cm}$ & 38,66 & 3 & 2 & 6 \\
Suhu & ${ }^{\circ} \mathrm{C}$ & 31,54 & 2 & 3 & 6 \\
Kedalaman & $\mathrm{cm}$ & 61 & 2 & 4 & 8 \\
Salinitas & $\mathrm{ppt}$ & 25,46 & 2 & 4 & 8 \\
$\mathrm{Ph}$ & & 6,65 & 2 & 3 & 6 \\
$\mathrm{DO}$ & $\mathrm{Mg} / 1$ & 3,60 & 1 & 3 & 3 \\
$\mathrm{CO}_{2}$ & $\mathrm{Mg} / 1$ & 1,97 & 2 & 3 & 6 \\
Fosfat & $\mathrm{Mg} / 1$ & 0,04 & 3 & 1 & 3 \\
Nitrat & $\mathrm{Mg} / 1$ & 0,22 & 3 & 2 & 6 \\
\hline \multicolumn{5}{r}{} \\
\hline
\end{tabular}

Dari Tabel 5 menunjukkan bahwa parameter yang sangat sesuai adalah kedalaman, parameter yang sesuai dan menunjang terhadap keberhasilan budidaya rumput laut adalah kecerahan, suhu, salinitas, $\mathrm{pH}$, DO, dan $\mathrm{CO}_{2}$, sedangkan parameter yang kurang sesuai adalah nitrat dan parameter yang tidak sesuai adalah fosfat.

Kriteria kesesuaian parameter fisika dan kimia untuk budidaya rumput laut menunjukkan bahwa pada Tabel 6 nilai parameter yang sangat sesuai atau memilki skor 4 adalah kedalaman, nilai parameter yang sesuai atau memiliki skor 3 adalah kecerahan, salinitas, $\mathrm{pH}, \mathrm{DO}, \mathrm{CO}_{2}$, nilai parameter yang kurang sesuai adalah suhu dan nitrat sedangkan nilai parameter yang tidak sesuai adalah fosfat. Pada Tabel 7 nilai parameter yang sangat sesuai adalah kedalaman dan $\mathrm{CO}_{2}$, nilai parameter yang sesuai atau memiliki skor 3 adalah kecerahan, salinitas, $\mathrm{pH}$, dan DO, yang kurang sesuai adalah suhu, fosfat dan nitrat. Pada Tabel 8, nilai parameter yang kurang sesuai atau memilki skor 2 adalah kecerahan, fosfat dan nitrat, nilai parameter yang sangat sesuai adalah kedalaman dan salinitas, nilai parameter yang sesuai adalah suhu, $\mathrm{pH}, \mathrm{DO}$ dan $\mathrm{CO}_{2}$. Pada Tabel 5, nilai parameter yang tidak sesuai atau memilki skor 1 adalah fosfat, nilai parameter yang sangat sesuai adalah kedalaman dan salinitas, nilai parameter yang sesuai adalah suhu, $\mathrm{pH}$, DO dan $\mathrm{CO}_{2}$, sedangkan yang kurang sesuai adalah kecerahan dan nitrat.

Dengan melihat dinamika parameter fisika, kimia air yang diamati di tambak Kecamatan Sinjai Timur, selanjutnya dilakukan perhitungan matriks kesesuaian lahan berdasarkan analisis parameter dilapangan kemudian dibandingkan dengan nilai kisaran parameter yang optimal pada tingkatan kelas kesesuaian lahan. Setiap peubah fisika dan kimia yang dijadikan tingkat kesesuaian pada semua stasiun pengambilan sampel, sudah merupakan integrasi dari beberapa peubah dengan empat kode kesesuain yaitu: sangat sesuai (S1), sesuai (S2), kurang sesuai (S3) dan tidak sesuai (N). Nilai dari hasil perhitungan matriks kesesuaian parameter fisika dan kimia air tambak akan di dapatkan kesesuaian tiap stasiun pengamatan lokasi di Tambak Kecamatan Sinjai Timur.

Berdasarkan hasil nilai perhitungan matriks kesesuaian parameter fisika kimia untuk budidaya rumput laut Gracilaria sp di tambak Kecamatan Sinjai Timur diketahui bahwa semua stasiun yakni Kelurahan Samataring, Desa Tongke-tongke, Desa Panaikang dan Desa Pasimarannu semuanya sesuai dengan nilai yang diperoleh berkisar $51-56$.

Tabel 6. Hasil Analisis Kesesuaian Parameter Fisika Kimia Air Tambak untuk Budidaya Rumput Laut Gracillaria sp di Kecamatan Sinjai Timur

\begin{tabular}{llll}
\hline Stasiun & $\begin{array}{l}\text { Nilai yang } \\
\text { diperoleh }\end{array}$ & Kriteria & Keterangan \\
\hline 1 & 51 & Sesuai & \\
2 & 56 & Sesuai & \\
3 & 55 & Sesuai & \\
4 & 52 & Sesuai & \\
\hline
\end{tabular}

Berdasarkan Tabel 6 menujukkan bahwa nilai

kesesuaian parameter kimia air tambak untuk pengembangan

budidaya rumput laut Gracillaria sp. di Kabupaten sinjai khususnya di Kecamatan Sinjai Timur semua sesuai.

\section{KESIMPULAN DAN SARAN}

Hasil penelitian menunjukkan bahwa parameter fisika dan kimia air tambak yang sangat sesuai untuk pengembangan budidaya rumput laut adalah kedalaman, parameter yang sesuai adalah kecerahan, suhu, salinitas, $\mathrm{pH}$, $\mathrm{DO}$ dan $\mathrm{CO}_{2}$, sedangkan parameter yang kurang sesuai adalah nitrat dan parameter yang tidak sesuai adalah fosfat. Hasil analisis kesesuaian parameter fisika dan kimia air untuk budidaya rumput laut Gracillaria sp di tambak Kecamatan Sinjai Timur meliputi Kelurahan Samataring, Desa Tongke-tongke, Desa Panaikang dan Desa Pasimarannu semuanya sesuai untuk pengembangan budidaya rumput laut gracillaria $\mathrm{sp}$ dengan kisaran nilai $51-56$.

\section{DAFTAR PUSTAKA}

Agustang, A., Mulyani, S., \& Indrawati, E. (2019). Analisis Kelayakan Lahan Budidaya Rumput Laut Gracilaria Sp Di Tambak Kecamatan Sinjai Utara Kabupaten Sinjai. Journal of Aquaculture and Environment, 2(1), 18-22.

Ariyati, R. W., L. Sya'rani, dan E. Arini. 2007. Analisis Kesesuaian Perairan Pulau Karimunjawa dan Pulau Kemujan sebagai Lahan Budidaya Rumput Laut Menggunakan Sistem Informasi Geografis. Jurnal Pasir Laut. 3(1): 27-45.

Budi, S., \& Aslamsyah, S. (2011). Improvement of the Nutritional Value and Growth of Rotifer (Brachionus 
plicatilis) by Different Enrichment Period with Bacillus sp. Jurnal Akuakultur Indonesia, 10(1), 67-73.

Budi, S., \& Zainuddin, Z. (2012). Peningkatan Asam Lemakrotifer Brachionus Plicatilis Dengan Periode Pengkayaan Bakteri Bacillus Sp. Berbeda. Octopus: Jurnal Ilmu Perikanan, 1(1), 1-5.

Budi, S., Karim, M. Y., Trijuno, D. D., Nessa, M. N., Gunarto, G., \& Herlinah, H. (2016). The use of fatty acid omega-3 HUFA and Ecdyson Hormone To Improve Of Larval Stage Indeks and Survival Rate Of Mud Crab Scylla olivacea. Simposium Nasional Kelautan dan Perikanan, 3, 487-498.

Budi, S., Karim, M. Y., Trijuno, D. D., Nessa, M. N., \& Herlinah, H. (2018). Pengaruh Hormon Ecdyson Terhadap Sintasan Dan Periode Moulting Pada Larva Kepiting Bakau Scylla olivacea. Jurnal Riset Akuakultur, 12(4), 335-339.

DKP . 2014. Statistik Kelautan dan Perikanan Kabupaten Sinjai Tahun 2014. Dinas Kelautan dan Perikanan Kabupaten Sinjai. Sinjai.

Faidar, F., Budi, S., \& Indrawati, E. (2020). Analisis Pemberian Vitamin C Pada Rotifer dan Artemia Terhadap Sintasan, Rasio Rna/Dna, Kecepatan Metamorfosis Dan Ketahanan Stres Larva Rajungan (Portunus Pelagicus) Stadia Zoea. Journal of Aquaculture and Environment, 2(2), 30-34.

Indriyani, S., Mahyuddin, H., \& Indrawati, E. (2019). Analisa Faktor Oseanografi Dalam Mendukung Budidaya Rumput Laut Kappaphycus Alvarezii Di Perairan Pulau Sembilan Kabupaten Sinjai. Journal of Aquaculture and Environment, 2(1), 6-11.

Kementerian Kelautan dan Perikanan. 2015. Laporam Produksi Budidaya Rumput Laut.Ditjen Perikanan Budidaya Kementerian Kelautan dan Perikanan Republik Indonesia. Jakarta.

Mubarak, H., S. Ilyas., W. Ismail., W. Hartati, .,E. Pratiwi., Z. Jangakru dan R. Arifuddin. 1990. Petunjuk Tekhnis Budidaya Rumput Laut. Badan Litbang Pertanian, Puslitbang Perikanan.

Neksidin., U,K. Pangerang dan Emiyarti. 2013. Studi Kualitas Air untuk Budidaya Rumput Laut (Kappaphycus alvarezii) di Perairan Teluk Kolono Kabupaten Konawe Selatan. Jurnal Mina Laut Indonesia Vol. 3 No. 12: 147-155.

Padawan, F., Indrawati, E., \& Mulyani, S. (2020). Analisis Lokasi Budidaya Terhadap Kandungan Karagenan Rumput Laut (Kappaphicus Alvarezii) Di Perairan Teluk Kosiwo Yapen - Papua. Journal of Aquaculture and Environment, 3(1), 11-14.

Sadhori, N. 1992. Budidaya Rumput Laut. Balai Pustaka. Semarang.

Saleh, J., Budi, S., \& Salam, S. (2019). Prospek Kelayakan Pengembangan Budidaya Ikan Nila Di Kolam Air Tenang Di Kecamatan Sinjai Borong Kabupaten Sinjai. Journal of Aquaculture and Environment, 2(1), 12-17.

Indriyani, S., Mahyuddin, H., \& Indrawati, E. (2019). Analisa Faktor Oseanografi Dalam Mendukung Budidaya Rumput Laut Kappaphycus alvarezii di Perairan Pulau Sembilan
Kabupaten Sinjai. Journal of Aquaculture and Environment, 2(1), 6-11.

Yunus, A. R., Budi, S., \& Salam, S. (2019). Analisis Kelayakan Lokasi Budidaya Metode Karamba Jaring Apung Di Perairan Desa Pulau Harapan Sinjai. Journal of Aquaculture and Environment, 2(1), 1-5. 